\title{
The effect of authentic assessment on academic achievement and attitude towards educational measurement and opinions of prospective teachers
}

\author{
Ceyhun Ozan \\ Department of Curriculum and Instruction, Ataturk University, Turkey
}

\begin{tabular}{l} 
Article Info \\
\hline Article history: \\
Received Mar 12, 2019 \\
Revised Apr 23, 2019 \\
Accepted May 19, 2019 \\
\hline
\end{tabular}

Keywords:

Academic achievement Attitude

Authentic assessment Prospective teachers Teacher training

\begin{abstract}
The aim of the study was to investigate the effect of authentic assessment on the attitudes of prospective teachers towards academic achievement and attitudes towards educational measurement and the opinions of prospective teachers on authentic assessment. In this study, the triangulation mixed design was used. In the quantitative dimension of the study, the study group consisted of prospective teachers studying in the education faculty of a state university in the 3rd grade of the Turkish education program of the 20162017 fall semesters. All prospective teachers in the experimental group filled in the unstructured diaries from which qualitative data were obtained and 12 of the prospective teachers in the experimental group were selected. Experimental processes were carried out during the 14-weeks assessment and evaluation course. In the experimental group, prospective teachers were given authentic assignments within the scope of the authentic task and alternative assessment practices were conducted. As a result of the study, it was determined that authentic assessment significantly increased the academic achievement and attitude towards the educational measurement of prospective teachers and also it's an approach that can serve to provide cooperation between the theory and practice which is a major problem in the field of teacher training in Turkey.
\end{abstract}

Copyright (C) 2019 Institute of Advanced Engineering and Science. All rights reserved.

\section{Corresponding Author:}

Ceyhun Ozan,

Department of Curriculum and Instruction,

Ataturk University, Erzurum County, 25000, Turkey.

Email: ozanceyhun@atauni.edu.tr

\section{INTRODUCTION}

Traditional assessments focusing on the written or oral examination of knowledge can be effective in assessing the student's ability to memorize and redefine the knowledge-based components of the task. However, they are insufficient to measure learning and skills unless traditional assessments are integrated with performance-based assessments, such as authentic assessment, to reflect the achievement of expected standards $[1,2]$. In the constructivist learning approach, assessment is part of the teaching process and is carried out not only in the beginning and in the end of learning but also throughout the learning process. Because the constructivist approach focuses on the process, it requires more and various measurement tools or methods than the traditional approach [3].

Traditional exams cannot capture the actual changes in students' knowledge. On the contrary, assessment methods that emphasize the learning process and encourage students to participate in metacognitive and reflective activities are compatible with the constructivist perspective. Authentic assessment or performance assessment represents such an alternative assessment methodology. The assessment is based on authentic learning tasks instead of exams only, and focuses on the learning process as much as (or more) the final outputs [4]. In this manner, Stiggins and Chappuis [5] pointed out that the quality 
of the assessment should be measured according to the students' real abilities. They also stated that the real assessment objective was about achieving learning and not limited to assessing learning. Students must be included in the assessment process in order to obtain the true meaning of authentic assessment.

Gulikers, Bastiaens, and Kirschner [6] describe authentic assessment in the context of vocational training, which includes competency-based training programs and assessments. Assessment tasks to be used in vocational training should be similar to the tasks that students will encounter in their future professional practice in order to better prepare students for future works. Authentic assessments in competence-based education should create opportunities that allow students to integrate learning and practice, resulting in mastery of professional skills that students will need in their future workplace. The purpose of authentic assessment is to provide students with the opportunity to engage in authentic tasks to develop, use and expand their knowledge, high-level thinking skills and other 21 st century competences. Since the 1990s, teacher training and professional development programs in many educational systems around the world have focused on the development of assessment literacy, including teacher competence to provide in-depth learning of teachers and pre-service teachers and to meet 21 st century competences in the design, adaptation and use of authentic assessment or performance assessment tasks [7-9].

Authentic tasks not only assess students' authentic performances or studies, but also evaluate their ability such as persistence in solving complex problems, positive habits of mind, growth mindset, resilience and grit, and self-directed learning. The use of analytical or holistic rubrics, which is an important component of authentic assessment, provides criteria and standards for descriptive feedback, self- and peer assessment. It is important that students receive timely and formative feedback from teachers and/or peers to improve their performance and work [10].

Wiggnis [11, 12] identified seven criteria for authentic assessment: (1) Authentic assessment is "realistic". If a student's knowledge, skills and/or tendencies are assessed in the real life context, this means that they should be assessed in authentic tasks. (2) Authentic tasks require students to make good decisions and to be creative and innovative in solving complex and non-routine problems or performing a task in new situations. (3) An authentic assessment or task enables students to participate in a subject or discipline through critical thinking and inquiry. (4) In authentic assessment, students are given the opportunity to repeatation, practice, find useful resources and receive timely feedback to improve performance or product quality. (5) Authentic tasks seek multiple evidence of student performance and the reasons or explanations behind the success and failure of a performance. (6) A multiple scoring system is used and the scoring criteria must be transparent. Clearly sharing the scoring criteria with the students will enable them to understand and internalize the criteria for success. (7) Students' self-assessments should play a very important role in authentic assessment.

According to the related literature, there are some studies determining that authentic assessment affects positively students' learning level and quality $[13,14]$, autonomy $[15,16]$, motivation $[17,18]$, selfregulation [19] and metacognitive skills [20, 21]. Authentic assessment has important problems as well as various benefits. The first of all these problems, systems with strong "testing" traditions come from the challenge of designing and implementing authentic assessment [22]. The research shows that authentic assessment is an effective assessment approach at higher education level. Therefore, it will be important to investigate the effect of authentic assessment on academic achievement and attitude towards educational measurement in teacher education and to examine the views of prospective teachers about authentic assessment.

In Turkey, a limited number of authentic assessment was conducted various studies [23-29]. Among these studies, Bay et al. [24], Koçyiğit [29], Kinay [27] and Kinay and Bağçeci [28] are related to prospective teachers. Bay et al. [24] examined the effect of authentic assessment on the achievement and attitude towards the course; moreover, Kinay [27] analysed the effect of authentic assessment upon problem solving skills, learning and participatory evaluation beliefs; Koçyiğit [29] the effect of authentic task-assisted constructivist approach on achievement, attitude towards course and problem-solving skills. Kinay and Bahçeci [28] examined the opinions of the prospective teachers about authentic assessment by qualitative research method. This research, unlike the existing research, aims to investigate authentic assessment with a mixed research method that uses both quantitative and qualitative methods. In addition, no studies have been found in the literature on the effect of authentic assessment on the attitude towards educational measurement, which is one of the dependent variables of the study. For these reasons, it can be said that the research will make a significant contribution to the related literature.

The aim of the study was to investigate the effect of authentic assessment on the attitudes of prospective teachers towards academic achievement and attitudes towards educational measurement and the opinions of prospective teachers on authentic assessment.

Int. J. Eval. and Res. Educ. Vol. 8, No. 2, June 2019: 299 - 312 


\section{METHOD}

\subsection{Research design}

In this research, a mixed method with a combination of quantitative and qualitative methods was used. The research was designed according to the triangulation design where both quantitative and qualitative data are collected simultaneously. In the quantitative dimension of the research, a nonequivalent quasiexperimental design with pre-test post-test control group was used. This model, which is widely used in educational research, includes experimental, control groups, pre-test, and post-test applications. However, the groups are naturally occurring and may not be equal before the experiment. Participants should be treated as much as possible. Each one of the groups is randomly selected as experiment and control group [30]. In this study, experimental and control groups were formed by random selection from existing classes considering similar characteristics. The qualitative dimension of the study was a case study. Yin [31] describes the case study as a research method that is used in cases where there is more than one data source and a current phenomenon is not clear in the precise lines of the boundaries between the fact and the content.

\subsection{Study group}

In the quantitative dimension of the study, the study group consisted of prospective teachers studying in the education faculty of a state university in the 3rd grade of Turkish education program of 20162017 fall semester. The students at the third year of the Turkish education program, one of the two branches of the Turkish education program was determined as the control group and the other one was selected as the experimental group. There were 50 prospective teachers and 45 prospective teachers in the control group. In the qualitative dimension of the study, the study group consisted of prospective teachers in the experimental group. All prospective teachers in the experimental group filled in the reflective diaries from which qualitative data were obtained and 12 of the prospective teachers in the experimental group were selected according to the maximum diversity sampling method, which is one of the purposive sampling methods for semi-structured interviews. In order to achieve maximum variation, gender and grade point average of prospective teachers were taken into consideration. Prospective teachers are 6 females and 6 males. 4 out of prospective teachers have a GPA below 2.5; 4 of between 2.5 and 3.00 and 4 of over 2.5.

\subsection{Process}

Experimental processes were carried out during the 14-weeks assessment and evaluation course. In the experimental group, authentic assessment practices were performed. Practices were carried out as group work. Within the scope of the authentic assessment, alternative assessment practices (portfolio, performance assessment, self-assessment, peer review, group evaluation, concept map, structured grid, diagnostic branched tree, word test and reflective diaries) were applied to the prospective teachers together with the authentic task.

Authentic task: Prospective teachers implemented the exams prepared by the group in the class within the scope of authentic task in a secondary school, which they had previously determined and performed their statistical analysis by scoring the exams. Secondary schools are authentic environments because they are places where prospective teachers are expected to serve in the future. The exams prepared by prospective teachers are related to the Turkish course and consist of different types of questions. The exams prepared by the group were presented in the measurement and evaluation course before they were implemented it in any secondary school. Prospective teachers made pre-interviews were with school principals and teachers for the exams. So, these interviews were handled in the context of problem solving which is an important feature of authentic tasks.

Portfolio: Teacher candidates put all the work they did in the semester into the student portfolio. The portfolios were delivered to the instructor at the end of the semester. The portfolios gained value as a final grade with the observation and evaluation of the instructor during the period. In the portfolio, the exams that are prepared within the scope of authentic task and applied in secondary school, rubrics for self, peer and group assessment, concept map, structured grid, diagnostic branched tree and word tests, studies on the subject of statistics and reflective diaries prepared by the students are included.

Self, peer and group assessments: Prospective teachers made weekly, peer and group assessments with rubrics which consisted of the criteria prepared by the lecturer on the subject of the week. The assessments were kept in the portfolio.

Concept map, structured grid, diagnostic branched tree and word test: Prospective teachers prepared concept map, structured grid, diagnostic branched tree and word test related to the subjects included in the secondary school Turkish course curriculum. The studies were kept in the portfolio.

Reflective diaries: Each prospective teacher kept a diary to reflect his/her evaluations on the course process and, in particular, on authentic assessment. The diaries both influenced the achievement grade of the prospective teachers and were used as a qualitative data collection tool in the research.

The effect of authentic assessment on academic achievement and attitude towards... (Ceyhun Ozan) 
In the control group, authentic assessment (authentic task and alternative assessment) applications were not included.

\subsection{Data collection tools}

Measurement and Evaluation Achievement Test, Attitude toward Educational Measurement Inventory, Semi-Structured Interview Form and Unstructured Diaries were used as data collection tools.

Measurement and Evaluation Achievement Test: The researcher created it after the item analysis of the multiple choice questions prepared in the assessment and evaluation course given in the fall semester of 2015-2016. According to the item analysis, questions with a degree of discrimination of more than 0.30 were selected in such a way that they would not impair the validity of the test. Multiple choice questions 40 in the achievement test. The KR-20 reliability coefficients were calculated as .87 and .89 for pre-test and post-test.

Attitude toward Educational Measurement Inventory: It was developed by Bryant and Barnes [32] and adapted to Turkish by Ozan and Köse [33]. The inventory consists of 31 items in three dimensions, 5point Likert type, which are of "relevance", "affective" and "course". The Cronbach's Alpha reliability coefficients ranged from .70 to .92 according to the overall inventory and sub-dimensions of the inventory for pre-test and post-test.

Semi-Structured Interview Form: The semi-structured interview form used for qualitative data collection was developed by the researcher and consists of five open-ended questions. For the validity of the content, the instructor was in the curriculum and instruction field and the opinions of the four experts who took the measurement and evaluation courses were applied. Then, the pre-interview was conducted with four students in the experimental group and the final form was given.

Unstructured Diaries: Another data collection tool used for collecting qualitative data is unstructured diaries. The diaries kept by each prospective teacher include the course process during the 14week course and reflections on authentic assessments. In addition, diaries were used as one of the alternative assessment tools in the course.

\subsection{Data analysis}

The quantitative data collected via data collection instruments was analyzed via SPSS-23 package program. In the analysis of quantitative data, independent samples t test, paired samples t test, analysis of covariance (ANCOVA) and multivariate analysis of covariance (MANCOVA) were used after normality and other test assumptions were met.

In the analysis of qualitative data, content analysis approach was adopted. Data obtained from interview form and diaries were presented together. The data obtained from the interview form and the diaries were analyzed by two researchers, both of the researchers working as an instructor in the field of curriculum and instruction. Data was divided into code and categories according to content analysis. In order to ensure the reliability between the encoders, Reliability = Agreements / (Agreements + Disagreement) reliability formula proposed by Miles and Huberman [34] was used. According to this formula, the coding reliability was calculated as .88 .

\section{RESULTS AND DISCUSSION}

\subsection{Quantitative findings}

Table 1 shows the academic achievement pre-test scores of the control and experimental group before the experimental procedures. According to Table 1, there is no significant difference between the pretest scores of the control and experimental group $(t=.067 ; \mathrm{p}=.947)$.

Table 1. Pre-test results of academic achievement

\begin{tabular}{llcccccc}
\hline Dependent variable & Group & $\mathrm{n}$ & $\mathrm{X}$ & $\mathrm{Sd}$ & $\mathrm{df}$ & $\mathrm{t}$ & $\mathrm{p}$ \\
\hline \multirow{2}{*}{ Academic achievement } & Control & 45 & 27.53 & 10.67 & \multirow{2}{*}{93} & \multirow{2}{*}{067} & \multirow{2}{*}{.947} \\
& Experimental & 50 & 27.40 & 8.70 & & & \\
\hline
\end{tabular}

Table 2 shows the attitudes toward educational measurement pre-test scores of the control and experimental group before the experimental procedures; there is no significant difference between the pretest scores of the control and experimental group for the attitudes toward educational measurement $(\mathrm{t}=.036$; $\mathrm{p}=.947)$. Table 3 shows the pre-test and post-test academic achievement scores of the control and experimental group.

Int. J. Eval. and Res. Educ. Vol. 8, No. 2, June 2019: 299 - 312 
Table 2. Pre-test results of attitudes toward educational measurement

\begin{tabular}{|c|c|c|c|c|c|c|c|}
\hline Dimensions & Group & $\mathrm{n}$ & $X$ & $\mathrm{Sd}$ & df & $\mathrm{t}$ & $\mathrm{p}$ \\
\hline \multirow{2}{*}{ Relevance } & Control & 45 & 3.97 & .59 & \multirow{2}{*}{93} & \multirow{2}{*}{.213} & \multirow{2}{*}{.831} \\
\hline & Experimental & 50 & 3.94 & .52 & & & \\
\hline \multirow{2}{*}{ Affective } & Control & 45 & 3.37 & .55 & \multirow{2}{*}{93} & \multirow{2}{*}{-.013} & \multirow{2}{*}{.990} \\
\hline & Experimental & 50 & 3.37 & .48 & & & \\
\hline \multirow{2}{*}{ Course } & Control & 45 & 3.31 & .40 & \multirow{2}{*}{93} & \multirow{2}{*}{-.339} & \multirow{2}{*}{.735} \\
\hline & Experimental & 50 & 3.33 & .37 & & & \\
\hline \multirow{2}{*}{ General } & Control & 45 & 3.60 & .41 & \multirow{2}{*}{93} & \multirow{2}{*}{.036} & \multirow{2}{*}{.971} \\
\hline & Experimental & 50 & 3.59 & .34 & & & \\
\hline
\end{tabular}

Table 3. Academic achievement pre-test and post-test mean and standard deviation values

\begin{tabular}{lllll}
\hline Dependent variable & Group & $\mathrm{n}$ & $\mathrm{X}$ & $\mathrm{Sd}$ \\
\hline & Control Pre-test & 45 & 27.53 & 10.67 \\
& Control Post-test & 45 & 49.02 & 14.45 \\
Academic achievement & Experimental Pre-test & 50 & 27.40 & 8.70 \\
& Experimental Post-test & 50 & 58.34 & 12.45 \\
\hline
\end{tabular}

According to Table 3 the pre-test and post-test scores, it was determined that the academic achievement scores of both the control and the experimental group increased. Table 4 shows the ANCOVA results of the significant difference between the post-test academic achievement scores of the control and experimental groups.

Table 4. Academic achievement ANCOVA results

\begin{tabular}{lccccc}
\hline Source of Variance & Sum of Squares & df & Mean of Squares & F & p \\
\hline Covariate variable (Pre-test) & 2746.068 & 1 & 2746.068 & 17.999 & .000 \\
Group & 2023.303 & 1 & 2023.303 & 13.262 & .000 \\
Error & 14036.130 & 92 & 152.567 & & \\
Total & 18838.484 & 94 & & & \\
\hline
\end{tabular}

When the pre-test scores were covariated, according to Table 4, a significant difference was found between the control and experimental groups post-test academic achievement scores. $(\mathrm{F}=13.262 ; \mathrm{p}=.000)$. Table 5 shows the mean and standard deviation values of the control and experimental group's attitude scores according to dimensions. 
Table 5. Attitudes towards educational measurement pre-test and post-test mean and standard deviation values

\begin{tabular}{lllll}
\hline Dimensions & Group & $\mathrm{n}$ & $\mathrm{X}$ & $\mathrm{Sd}$ \\
\hline \multirow{4}{*}{ Relevance } & Control Pre-test & 45 & 3.97 & .59 \\
& Control Post-test & 45 & 4.11 & .55 \\
& Experimental Pre-test & 50 & 3.94 & .52 \\
& Experimental Post-test & 50 & 4.43 & .66 \\
\multirow{3}{*}{ Affective } & Control Pre-test & 45 & 3.37 & .55 \\
& Control Post-test & 45 & 3.48 & .75 \\
& Experimental Pre-test & 50 & 3.37 & .48 \\
& Experimental Post-test & 50 & 3.92 & .84 \\
Course & Control Pre-test & 45 & 3.31 & .40 \\
& Control Post-test & 45 & 3.58 & .70 \\
& Experimental Pre-test & 50 & 3.33 & .37 \\
& Experimental Post-test & 50 & 4.02 & .86 \\
General & Control Pre-test & 45 & 3.60 & .41 \\
& Control Post-test & 45 & 3.77 & .54 \\
& Experimental Pre-test & 50 & 3.59 & .34 \\
& Experimental Post-test & 50 & 4.16 & .69 \\
\hline
\end{tabular}

According to Table 5, it was determined that both the control and the experimental groups' pre-test and post-test scores for the educational assessment were increased. Table 6 shows the MANCOVA results of the significant difference between the control and experimental group's post-test scores for the attitudes towards educational assessment.

Table 6. Attitude towards educational assessment MANCOVA results

\begin{tabular}{llllll}
\hline & Value & F & Hypothesis df & Error df & p \\
\hline Wilks' Lambda & .914 & 2.772 & 3 & 88 & .046 \\
\hline
\end{tabular}

When the pre-test scores were covariated, according to Table 6 , significant difference was found between the control and experimental group's post-test scores for the attitudes towards educational assessment. ( $\mathrm{F}=2.772 ; \mathrm{p}=.046)$. Table 7 shows the significant differences in the dimensions of the scale.

Table 7. MANCOVA results according to the scale of attitude towards educational measurement

\begin{tabular}{llllll}
\hline & Sum of Squares & $\mathrm{df}$ & Mean of Squares & $\mathrm{F}$ & $\mathrm{p}$ \\
\hline Relevance & 2.326 & 1 & 2.326 & 6.123 & .015 \\
Affective & 4.394 & 1 & 4.394 & 6.875 & .010 \\
Course & 3.931 & 1 & 3.931 & 6.496 & .013 \\
General & 3.339 & 1 & 3.339 & 8.441 & .005 \\
\hline
\end{tabular}

According to Table 7, according to the scores of the control and experimental group, there is a significant difference for both the scale and the sub-dimensions of the scale. The post-test attitude scores of the experimental group were significantly higher than the posttest attitude scores of the control group of all dimensions.

\subsection{Qualitative findings}

Content analysis resulted in five categories: Affective dimension, Positive aspects, Negative aspects, Attitude towards the course, Usability in other courses. Table 8 and subsequent descriptions are related to how students feel during the practice of authentic task.

Int. J. Eval. and Res. Educ. Vol. 8, No. 2, June 2019: 299 - 312 
Table 8. Students' feels during the authentic task practice

\begin{tabular}{|c|c|c|}
\hline Category & $\mathrm{f}$ & Codes \\
\hline & 30 & $\begin{array}{l}\text { The sense of teaching ( } \mathrm{S}_{7}, \mathrm{~S}_{8}, \mathrm{~S}_{9}, \mathrm{~S}_{12}, \mathrm{~S}_{13}, \mathrm{~S}_{15}, \mathrm{~S}_{19}, \mathrm{~S}_{20}, \mathrm{~S}_{21}, \mathrm{~S}_{22}, \mathrm{~S}_{24}, \mathrm{~S}_{26}, \mathrm{~S}_{28} \\
\left.\mathrm{~S}_{30}, \mathrm{~S}_{31}, \mathrm{~S}_{33}, \mathrm{~S}_{34}, \mathrm{~S}_{35}, \mathrm{~S}_{37}, \mathrm{~S}_{38}, \mathrm{~S}_{40}, \mathrm{~S}_{41}, \mathrm{~S}_{42}, \mathrm{~S}_{43}, \mathrm{~S}_{44}, \mathrm{~S}_{45}, \mathrm{~S}_{46}, \mathrm{~S}_{49}, \mathrm{~S}_{50}\right)\end{array}$ \\
\hline A1 & 29 & $\begin{array}{l}\text { Happiness, delightful }\left(\mathrm{S}_{4}, \mathrm{~S}_{1}, \mathrm{~S}_{9}, \mathrm{~S}_{11}, \mathrm{~S}_{14}, \mathrm{~S}_{16}, \mathrm{~S}_{17}, \mathrm{~S}_{18}, \mathrm{~S}_{19}, \mathrm{~S}_{20}, \mathrm{~S}_{24}, \mathrm{~S}_{25}, \mathrm{~S}_{28}, \mathrm{~S}_{29} \text {, }\right. \\
\left.\mathrm{S}_{32}, \mathrm{~S}_{33}, \mathrm{~S}_{34}, \mathrm{~S}_{35}, \mathrm{~S}_{36}, \mathrm{~S}_{37}, \mathrm{~S}_{38}, \mathrm{~S}_{39}, \mathrm{~S}_{41}, \mathrm{~S}_{42}, \mathrm{~S}_{44}, \mathrm{~S}_{47}, \mathrm{~S}_{48}, \mathrm{~S}_{49}, \mathrm{~S}_{50}\right)\end{array}$ \\
\hline \multirow{3}{*}{$\begin{array}{l}\text { Affective } \\
\text { dimension }\end{array}$} & 28 & $\begin{array}{l}\text { Exciting }\left(\mathrm{S}_{2}, \mathrm{~S}_{4}, \mathrm{~S}_{5}, \mathrm{~S}_{6}, \mathrm{~S}_{7}, \mathrm{~S}_{13}, \mathrm{~S}_{14}, \mathrm{~S}_{15}, \mathrm{~S}_{17}, \mathrm{~S}_{18}, \mathrm{~S}_{19}, \mathrm{~S}_{22}, \mathrm{~S}_{23}, \mathrm{~S}_{29}, \mathrm{~S}_{30}, \mathrm{~S}_{31}, \mathrm{~S}_{32}\right. \\
\left.\mathrm{S}_{34}, \mathrm{~S}_{35}, \mathrm{~S}_{37}, \mathrm{~S}_{38}, \mathrm{~S}_{39}, \mathrm{~S}_{40}, \mathrm{~S}_{41}, \mathrm{~S}_{42}, \mathrm{~S}_{44}, \mathrm{~S}_{45}, \mathrm{~S}_{50}\right)\end{array}$ \\
\hline & 6 & Motivating $\left(\mathrm{S}_{5}, \mathrm{~S}_{27}, \mathrm{~S}_{41}, \mathrm{~S}_{43}, \mathrm{~S}_{49}, \mathrm{~S}_{50}\right)$ \\
\hline & 1 & Fear $\left(\mathrm{S}_{39}\right)$ \\
\hline
\end{tabular}

Table 8 shows that students' views about what they feel during the authentic task are very similar. It could be said that the opinions focused on the sense of teaching, excitement and happiness. Student $\mathrm{S}_{2}$ emphasizes that they are excited about putting themselves under a teacher. Student $S_{3}$ stated that it was a great feeling for them to be interested in children. Student $\mathrm{S}_{4}$ stated that it was very nice to experience authentic task practice and it excited me. This is evident in the one-to-one quotations from students:

Student $\mathrm{S}_{3:}$... Being really interested in children, when they ask questions, they can help us look into our eyes, and behave as if we are really teachers, and I am a person who loves children very much. It was nice to be there with them. ...

Student $\mathrm{S}_{4}$ : So it is a very simple application, but it was our first experience after all. It made you feel a different emotion, both thrilled ...

Student $\mathrm{S}_{6}$ : For the first time, I was on the test, not the exam. That was very exciting.

Student $\mathrm{S}_{10}$ : For every student, winning a university is a goal. You do not have any idea what is going on until you graduate. You will continue to read and pass exams, just to pass without learning about the environment, the location, and the difficulties of your work. With this practice, I believe that I have broken down this taboo. When I graduate, I know what is waiting for the environment and me. In addition, it is such a feeling that the recipe is impossible. All I can say is, yes, I am in the right department.

Student $\mathrm{S}_{34}$ : In this application, I felt myself a complete teacher. I have learned with this practice what a beautiful profession it is. I was very excited and enjoyed it during the application.

Student $\mathrm{S}_{39}$ : Of course, there was a lot of excitement. Because we were in a real environment. There was a sense of fear except for the excitement. I think I was very nervous because it was the first experience. However, in spite of everything, it was very special to live and feel that moment.

Table 9 and the following descriptions about the positive aspects of the application made in the scope of authentic tasks.

Table 9. Students' views on the positive aspects of authentic tasks

\begin{tabular}{|c|c|c|}
\hline Category & f & Codes \\
\hline \multirow[b]{5}{*}{ A2 } & 23 & $\begin{array}{l}\text { Professional experience }\left(\mathrm{S}_{2}, \mathrm{~S}_{6}, \mathrm{~S}_{7}, \mathrm{~S}_{11}, \mathrm{~S}_{15}, \mathrm{~S}_{18}, \mathrm{~S}_{19}, \mathrm{~S}_{20}, \mathrm{~S}_{21}, \mathrm{~S}_{22}, \mathrm{~S}_{23}, \mathrm{~S}_{26}, \mathrm{~S}_{28}, \mathrm{~S}_{29} \text {, }\right. \\
\left.\mathrm{S}_{30}, \mathrm{~S}_{31}, \mathrm{~S}_{32}, \mathrm{~S}_{35}, \mathrm{~S}_{36}, \mathrm{~S}_{40}, \mathrm{~S}_{44}, \mathrm{~S}_{49}, \mathrm{~S}_{50}\right)\end{array}$ \\
\hline & 17 & $\begin{array}{l}\text { Better learning }\left(\mathrm{S}_{2}, \mathrm{~S}_{3}, \mathrm{~S}_{5}, \mathrm{~S}_{22}, \mathrm{~S}_{26}, \mathrm{~S}_{27}, \mathrm{~S}_{34}, \mathrm{~S}_{35}, \mathrm{~S}_{37}, \mathrm{~S}_{39}, \mathrm{~S}_{40}, \mathrm{~S}_{41}, \mathrm{~S}_{42}, \mathrm{~S}_{43}, \mathrm{~S}_{45}, \mathrm{~S}_{47} \text {, }\right. \\
\left.\mathrm{S}_{50}\right)\end{array}$ \\
\hline & 14 & $\begin{array}{l}\text { Giving a sense of teaching }\left(\mathrm{S}_{9}, \mathrm{~S}_{10}, \mathrm{~S}_{13}, \mathrm{~S}_{14}, \mathrm{~S}_{16}, \mathrm{~S}_{17}, \mathrm{~S}_{18}, \mathrm{~S}_{23}, \mathrm{~S}_{36}, \mathrm{~S}_{38}, \mathrm{~S}_{41}, \mathrm{~S}_{42}, \mathrm{~S}_{46} \text {, }\right. \\
\left.\mathrm{S}_{47}\right)\end{array}$ \\
\hline & 9 & Ability to work in real field $\left(\mathrm{S}_{1}, \mathrm{~S}_{17}, \mathrm{~S}_{23}, \mathrm{~S}_{24}, \mathrm{~S}_{29}, \mathrm{~S}_{37}, \mathrm{~S}_{39}, \mathrm{~S}_{40}, \mathrm{~S}_{48}\right)$ \\
\hline & 9 & $\begin{array}{l}\text { Understand the importance of exam preparation and application }\left(\mathrm{S}_{6}, \mathrm{~S}_{8}, \mathrm{~S}_{9}, \mathrm{~S}_{13} \text {, }\right. \\
\left.\mathrm{S}_{15}, \mathrm{~S}_{23}, \mathrm{~S}_{33}, \mathrm{~S}_{34}, \mathrm{~S}_{48}\right)\end{array}$ \\
\hline Positive & 6 & Communicating with students, recognition $\left(\mathrm{S}_{1}, \mathrm{~S}_{2}, \mathrm{~S}_{4}, \mathrm{~S}_{5}, \mathrm{~S}_{22}, \mathrm{~S}_{38}\right)$ \\
\hline \multirow[t]{7}{*}{ Aspects } & 5 & Self-confidence $\left(\mathrm{S}_{12}, \mathrm{~S}_{14}, \mathrm{~S}_{19}, \mathrm{~S}_{21}, \mathrm{~S}_{34}\right)$ \\
\hline & 4 & Prioritize the task $\left(\mathrm{S}_{2}, \mathrm{~S}_{10}, \mathrm{~S}_{24}, \mathrm{~S}_{25}\right)$ \\
\hline & 3 & Gaining consciousness of responsibility $\left(\mathrm{S}_{9}, \mathrm{~S}_{17}, \mathrm{~S}_{21}\right)$ \\
\hline & 2 & $\begin{array}{l}\text { Providing the opportunity to supervise the suitability of the teacher as a } \\
\text { profession }\left(\mathrm{S}_{3}, \mathrm{~S}_{22}\right)\end{array}$ \\
\hline & 2 & Understand the importance of cooperation $\left(\mathrm{S}_{6}, \mathrm{~S}_{9}\right)$ \\
\hline & 2 & Increasing interest and motivation for the course $\left(\mathrm{S}_{26}, \mathrm{~S}_{27}\right)$ \\
\hline & 1 & Recognizing group friends $\left(\mathrm{S}_{16}\right)$ \\
\hline
\end{tabular}

When Table 9 is examined, it is seen that students' express different opinions about the positive aspects of authentic task practice. According to student $S_{17}$, the real environment and the opportunity to work with the student group they will encounter when they become teachers are positive aspects of authentic task practice. Student $\mathrm{S}_{17}$ expresses this situation as follows:

The effect of authentic assessment on academic achievement and attitude towards... (Ceyhun Ozan) 
Student $\mathrm{S}_{17}$...If the anthropologist or the doctor work within their field, teachers should also be given the opportunity to create their own real field. Because for me, these are the real engineers. As a civil engineer, as a human engineer, as a human rearing engineer they should have given them more opportunities, I have experienced it. How did I live? Because we have prepared an exam for people at primary level and we went to the environment where those people if we had applied those questions to other students or other students in a different setting, we would not be able to enjoy that pleasure. The questions we had were children at primary level. We have seen this convenience because they are our correspondents and we performed it better with them.

According to the student $\mathrm{S}_{2}$, when they become teachers, they give a chance to get to know the place they will work, because they are practice-oriented rather than theoretical, they provide better learning and give them the opportunity to communicate one-to-one with the children. This situation is seen in the following statements of the student $\mathrm{S}_{2}$ :

Student $\mathrm{S}_{2}$ : ...The positive thing is that we knew the place we were going to work from the beginning. So we saw it, we observed it. Theoretically, it does not matter for you if you do it or not. So the application does not like. We saw it on the spot, we saw the difficulties. We observed everything. We tried to communicate with the children. We could or could not. It is not exactly, but we observed, at least we had experience.

Student $\mathrm{S}_{22}$, on the other hand, considers that the practice of authentic practice as an occupation gives the opportunity to control whether the teaching is suitable for him / her and to turn the theoretical education that $\mathrm{s} /$ he has taken into practice into practice. Student $\mathrm{S}_{22}$ 's expressions about these views are as follows:

Student $\mathrm{S}_{22}$...Do I really want to be a teacher? How efficient am I in the department I study? How much did I affect you? You are thinking about them. Therefore, this is obviously an opportunity for you. Because everything you see at school in one-to-one is alive there. You deal with the student, you exchange information. It was a good chance for me to really decide what I really wanted. I wish we had a year of education in this next four years, I wish I had done such applications, projects. Of course, if such opportunities occur, for example, one may draw the path at the very beginning. Because the pedagogical training you take is a lot different than applying it.

Student $\mathrm{S}_{38}$ also stated that providing the opportunity to see the level of students is the positive aspect of authentic tasks. The statements of this view are as follows:

Student $\mathrm{S}_{38}$ : The positive aspect ultimately is to make an implementation. We did this implementation for the sixth grade. They were able to determine what level they were at or to determine the level of reliability or general state of the test. It was useful in this respect; it was a good practice.

Student $\mathrm{S}_{5}$ : Teaching was a very positive thing. You realize what will happen in the future. You have the chance to beat your excitement. You get in touch with people and you know new faces. You understand how to behave in class, how to behave in class. We learned by living by doing lessons.

Student $S_{37}$ : Rather than just the theoretical knowledge, we learned at school, teaching has a more lasting effect. The question of how the theoretical knowledge will be applied will disappear. Because it gives the opportunity to live the environment in person and intervene immediately.

Table 10 and the following descriptions about students' opinions show the negative aspects of the implementation of the authentic task.

Table 10. Students' views on the negative aspects of authentic tasks

\begin{tabular}{|c|c|c|}
\hline Category & $\mathrm{f}$ & Codes \\
\hline \multirow{4}{*}{ A3 } & 22 & I do not think it is negative. $\left(\mathrm{S}_{3}, \mathrm{~S}_{7}, \mathrm{~S}_{10}, \mathrm{~S}_{11}, \mathrm{~S}_{14}, \mathrm{~S}_{19}, \mathrm{~S}_{20}, \mathrm{~S}_{22}, \mathrm{~S}_{24}, \mathrm{~S}_{26}, \mathrm{~S}_{32}, \mathrm{~S}_{36}\right.$, \\
\hline & 9 & $\begin{array}{l}\text { Difficulties of executives for implementation }\left(\mathrm{S}_{8}, \mathrm{~S}_{9}, \mathrm{~S}_{15}, \mathrm{~S}_{16}, \mathrm{~S}_{25}, \mathrm{~S}_{29}, \mathrm{~S}_{35}, \mathrm{~S}_{47} \text {, }\right. \\
\left.\mathrm{S}_{48}\right)\end{array}$ \\
\hline & 7 & Students know that they are not a real teacher $\left(\mathrm{S}_{2}, \mathrm{~S}_{4}, \mathrm{~S}_{23}, \mathrm{~S}_{30}, \mathrm{~S}_{33}, \mathrm{~S}_{34}, \mathrm{~S}_{46}\right)$ \\
\hline & 4 & Tiring $\left(\mathrm{S}_{12}, \mathrm{~S}_{17}, \mathrm{~S}_{28}, \mathrm{~S}_{34}\right)$ \\
\hline \multirow{7}{*}{$\begin{array}{l}\text { Negative } \\
\text { Aspects }\end{array}$} & 3 & Not giving grade $\left(\mathrm{S}_{2}, \mathrm{~S}_{4}, \mathrm{~S}_{21}\right)$ \\
\hline & 2 & Time consuming $\left(\mathrm{S}_{27}, \mathrm{~S}_{29}\right)$ \\
\hline & 1 & Application time is short $\left(\mathrm{S}_{45}\right)$ \\
\hline & 1 & Don't want to teach boring and difficult $\left(\mathrm{S}_{3}\right)$ \\
\hline & 1 & Teacher interfering too much $\left(\mathrm{S}_{5}\right)$ \\
\hline & 1 & Teacher's irrelevant $\left(\mathrm{S}_{6}\right)$ \\
\hline & 1 & Classes are crowded $\left(\mathrm{S}_{1}\right)$ \\
\hline
\end{tabular}

Int. J. Eval. and Res. Educ. Vol. 8, No. 2, June 2019: 299 - 312 
According to Table 10, it is seen that students $S_{2}$ and $S_{4}$ have similar opinions regarding the negative aspects of authentic task application while student $S_{1}$ and $S_{3}$ have different opinions. Student $S_{1}$ stated that the crowding of classes added negative to authentic duty. The students $S_{2}$ and $S_{4}$ stated that the children who were practiced did not see themselves as real teachers and that they knew that they could not take notes from the practice was the negative aspect of authentic tasks. Student $\mathrm{S}_{4}$, on the other hand, stated that there was no negative aspect of authentic task practice and that such tasks would be boring and difficult for those who did not want to teach. One-to-one quotations according to the students' statements are as follows:

Student $\mathrm{S}_{1}$ : ... That was the problem for us: Doing exams with more students. However, if we were to have fewer students, we could have questions that are more selective. We could be more like that. According to the results of exam reviews, it could have acted more individually. In this respect, there was nothing negative, so there was not much negativity in our part. However, the class was very crowded.

Student $\mathrm{S}_{2}:$... Negative aspects of an authentic task: Eeee, what can I say? When we went to the authentic task, the children did not really see us as anything. I mean, they did not really see me as a teacher. Maybe they would have been easier if we have seen them, but we did not do much because they were aware that we would not give a note, they were temporary applications...

Student $\mathrm{S}_{3}$ : ... Perhaps someone who is looking at the teaching profession in a different way or who does not want the profession of teaching may be boring, or what I know, could be an action that is difficult to deal with. However, I do not think they have any negative aspects, so I am aware that they have contributed to us.

Student $\mathrm{S}_{4}:$... When we said that the negative aspects were that we were not pointing to the note, there was a different point of view in the students, and accordingly our position there fell to a different position. This was the worst as we were not really teachers. Let us say they did not take much credibility, in that sense we experienced his distress.

Student $S_{48}$ : There was no negative side but we had serious problems in finding a school but we did it without giving up.

Table 11 and subsequent illustrations describe students' views on the impact of the practice on the attitude towards the course.

Table 11. Students' views on the effect of authentic task on their attitudes towards the course

\begin{tabular}{lll}
\hline Category & $\mathrm{f}$ & Codes \\
\hline & & Positive $\left(\mathrm{S}_{1}, \mathrm{~S}_{2}, \mathrm{~S}_{3}, \mathrm{~S}_{4}, \mathrm{~S}_{5}, \mathrm{~S}_{6}, \mathrm{~S}_{7}, \mathrm{~S}_{8}, \mathrm{~S}_{9}, \mathrm{~S}_{10}, \mathrm{~S}_{11}, \mathrm{~S}_{12}, \mathrm{~S}_{13}, \mathrm{~S}_{14}, \mathrm{~S}_{18}, \mathrm{~S}_{19}, \mathrm{~S}_{20}, \mathrm{~S}_{21}\right.$, \\
& 41 & $\begin{array}{l}\mathrm{S}_{22}, \mathrm{~S}_{24}, \mathrm{~S}_{25}, \mathrm{~S}_{26}, \mathrm{~S}_{27}, \mathrm{~S}_{28}, \mathrm{~S}_{29}, \mathrm{~S}_{30}, \mathrm{~S}_{32}, \mathrm{~S}_{33}, \mathrm{~S}_{36}, \mathrm{~S}_{37}, \mathrm{~S}_{38}, \mathrm{~S}_{41}, \mathrm{~S}_{42}, \mathrm{~S}_{43}, \mathrm{~S}_{44}, \mathrm{~S}_{45}, \\
\left.\mathrm{~S}_{46}, \mathrm{~S}_{47}, \mathrm{~S}_{48}, \mathrm{~S}_{49}, \mathrm{~S}_{50}\right)\end{array}$ \\
$\begin{array}{l}\text { Attitude towards } \\
\text { The Course }\end{array}$ & 9 & Unchanged $\left(\mathrm{S}_{15}, \mathrm{~S}_{16}, \mathrm{~S}_{17}, \mathrm{~S}_{23}, \mathrm{~S}_{31}, \mathrm{~S}_{34}, \mathrm{~S}_{35}, \mathrm{~S}_{39}, \mathrm{~S}_{40}\right)$ \\
\hline
\end{tabular}

According to Table 11, students have different views on the attitudes and points of view of authentic tasks. Student $\mathrm{S}_{1}$ stated that he understood the importance of the lesson better after authentic task practice, student $S_{2}$ was better motivated to the lesson and he got more sympathetic, student $S_{3}$ had a positive effect on the course point of view and student $\mathrm{S}_{4}$ learned the course better after this practice. When the students' opinions are evaluated in general, all of them are positive. The students emphasized that the practice of authentic practice positively affects their attitudes or perspectives. The students' statements on these views are as follows:

Student $\mathrm{S}_{1}$ :... After doing the application, we can understand the importance of this course better. The course was more important.

Student $\mathrm{S}_{2}$ : After the task or in fact this is our first practice, we started to approach a little sympathetic to this practice in terms of the lesson. The value given to us when we went to the classroom, the value given to us by the students we met, contributed much to us.

Student $\mathrm{S}_{3}$ :... We were the students in the measurement and evaluation course, but in practice, they were the opposite. We are the ones who are going to make the assessment and we really try to be equal and right here. This is a very important thing. In the end, what you measure and evaluate is in our own way. People are doubtly responsible for this issue. The first one is against the student, and the second is to be honest with yourself. Of course, my perspective on the course was affected.

Student $\mathrm{S}_{4}$ : ... When we learned about what was happening in this course, how it was grasped, what should be considered or what should be avoided, it taught us better.

Student $S_{25}$ : I had a negative attitude towards the class. This task corrected the situation little. 
Student $S_{26}$ : I was afraid of the measurement and evaluation course. Thanks to this app, the course came to me of interest. In the beginning when I was looking to move to class, this practice showed me that I should not just look at this lesson. I was positively impressed.

Table 12 and subsequent descriptions are about the opinions of the students about the usability of authentic tasks in teacher training in other subjects.

Table 12. Students' views on the availability of authentic tasks in other courses

\begin{tabular}{|c|c|c|}
\hline Category & $\mathrm{f}$ & Codes \\
\hline A5 & 35 & $\begin{array}{l}\text { All courses }\left(\mathrm{S}_{1}, \mathrm{~S}_{2}, \mathrm{~S}_{4}, \mathrm{~S}_{5}, \mathrm{~S}_{7}, \mathrm{~S}_{9}, \mathrm{~S}_{10}, \mathrm{~S}_{13}, \mathrm{~S}_{15}, \mathrm{~S}_{16}, \mathrm{~S}_{17}, \mathrm{~S}_{18}, \mathrm{~S}_{19}, \mathrm{~S}_{20}, \mathrm{~S}_{23}, \mathrm{~S}_{24}, \mathrm{~S}_{25}, \mathrm{~S}_{26},\right. \\
\left.\mathrm{S}_{27}, \mathrm{~S}_{29}, \mathrm{~S}_{30}, \mathrm{~S}_{31}, \mathrm{~S}_{32}, \mathrm{~S}_{33}, \mathrm{~S}_{34}, \mathrm{~S}_{35}, \mathrm{~S}_{36}, \mathrm{~S}_{37}, \mathrm{~S}_{38}, \mathrm{~S}_{42}, \mathrm{~S}_{44}, \mathrm{~S}_{47}, \mathrm{~S}_{48}, \mathrm{~S}_{49}, \mathrm{~S}_{50}\right)\end{array}$ \\
\hline Availability & 9 & In the appropriate course content $\left(\mathrm{S}_{11}, \mathrm{~S}_{12}, \mathrm{~S}_{14}, \mathrm{~S}_{21}, \mathrm{~S}_{22}, \mathrm{~S}_{40}, \mathrm{~S}_{41}, \mathrm{~S}_{45}, \mathrm{~S}_{46}\right)$ \\
\hline in Other & 4 & In class management course $\left(\mathrm{S}_{6}, \mathrm{~S}_{7}, \mathrm{~S}_{40}, \mathrm{~S}_{43}\right)$ \\
\hline Courses & 3 & Not suitable for other courses $\left(\mathrm{S}_{8}, \mathrm{~S}_{28}, \mathrm{~S}_{39}\right)$ \\
\hline & 1 & Especially in the language department $\left(\mathrm{S}_{3}\right)$ \\
\hline
\end{tabular}

Table 12 shows that students have similar opinions about the use of authentic tasks in courses other than assessment and evaluation. Student $\mathrm{S}_{1}$ and $\mathrm{S}_{4}$ stated that authentic tasks could be applied in all subjects, student $\mathrm{S}_{2}$ stated that it could be applied in all fields and student $\mathrm{S}_{3}$ stated that it should be applied especially in language departments. The students' statements on these views are as follows:

Student $\mathrm{S}_{1}$ : ... Applicable for all courses. Not just for lessons, for example, a grocery store can do it for itself. Also applicable in the business sector. Indeed, this assessment should not be addressed only to students of a course or to people with special courses at any place. I think it should show itself in many areas of life, and people should get this course into their own lives...

Student $\mathrm{S}_{2}$ : Authentic tasks can be used in everything I think. Therefore, not everything requires an application anyway. Those who study chemistry, for example, go to chemistry rooms, do lab work, or visit factories. There are things in the spinning mills. I think this method can be applied in every field.

Student $\mathrm{S}_{3}$ : ... Of course. I want to talk about verbal and mathematical fields. The language is completely different from all of them. Because language can only be learned by hearing, experiencing and living in that moment. Because the Turkish you learn in the university and the Turkish you give in the classroom will be as different as the mountains.

Student $\mathrm{S}_{4}$ : ... So all the lessons can be in the application, whatever my knowledge is, whether it is a physics lesson or a chemistry course, or whether it is done in the laboratory or talk about languages and do practices there to do something else, this should be done, it will provide a gain.

Student $\mathrm{S}_{35}$ : Such tasks should be included in our education system. Such authentic tasks should be applied in all other courses so that what we have learned does not remain in theory. If we want to educate a true and good teacher, we must support education with such tasks.

Student $\mathrm{S}_{50}$ : I think it is available for each course. The experience is made on the job site because it is the best experience.

in teacher training.

Table 13 and subsequent descriptions are about students' views on the importance of authentic tasks

Table 13. Students' views on the importance of authentic tasks in teacher training

\begin{tabular}{|c|c|c|}
\hline Category & $f$ & Codes \\
\hline A7 Importance & $\begin{array}{l}8 \\
7 \\
5 \\
2 \\
2 \\
1 \\
1 \\
1\end{array}$ & $\begin{array}{l}\text { It is very important. }\left(\mathrm{S}_{2}, \mathrm{~S}_{3}, \mathrm{~S}_{4}, \mathrm{~S}_{5}, \mathrm{~S}_{6}, \mathrm{~S}_{7}, \mathrm{~S}_{8}, \mathrm{~S}_{9}, \mathrm{~S}_{10}, \mathrm{~S}_{11}, \mathrm{~S}_{12}, \mathrm{~S}_{13}, \mathrm{~S}_{14}, \mathrm{~S}_{15} \text {, }\right. \\
\mathrm{S}_{16}, \mathrm{~S}_{17}, \mathrm{~S}_{18}, \mathrm{~S}_{19}, \mathrm{~S}_{20}, \mathrm{~S}_{21}, \mathrm{~S}_{22}, \mathrm{~S}_{23}, \mathrm{~S}_{24}, \mathrm{~S}_{25}, \mathrm{~S}_{26}, \mathrm{~S}_{27}, \mathrm{~S}_{28}, \mathrm{~S}_{29}, \mathrm{~S}_{30}, \mathrm{~S}_{31}, \mathrm{~S}_{32} \text {, } \\
\mathrm{S}_{33}, \mathrm{~S}_{34}, \mathrm{~S}_{35}, \mathrm{~S}_{36}, \mathrm{~S}_{37}, \mathrm{~S}_{38}, \mathrm{~S}_{39}, \mathrm{~S}_{40}, \mathrm{~S}_{41}, \mathrm{~S}_{42}, \mathrm{~S}_{43}, \mathrm{~S}_{44}, \mathrm{~S}_{45}, \mathrm{~S}_{46}, \mathrm{~S}_{47}, \mathrm{~S}_{48}, \mathrm{~S}_{49} \text {, } \\
\left.\mathrm{S}_{50}\right) \\
\text { Gaining professional experience }\left(\mathrm{S}_{2}, \mathrm{~S}_{5}, \mathrm{~S}_{6}, \mathrm{~S}_{7}, \mathrm{~S}_{8}, \mathrm{~S}_{10}, \mathrm{~S}_{11}, \mathrm{~S}_{14}, \mathrm{~S}_{15}, \mathrm{~S}_{21} \text {, }\right. \\
\left.\mathrm{S}_{22}, \mathrm{~S}_{23}, \mathrm{~S}_{24}, \mathrm{~S}_{26}, \mathrm{~S}_{27}, \mathrm{~S}_{29}, \mathrm{~S}_{30}, \mathrm{~S}_{32}, \mathrm{~S}_{33}, \mathrm{~S}_{34}, \mathrm{~S}_{42}, \mathrm{~S}_{48}, \mathrm{~S}_{49}\right) \\
\text { Application in real environment }\left(\mathrm{S}_{19}, \mathrm{~S}_{20}, \mathrm{~S}_{29}, \mathrm{~S}_{35}, \mathrm{~S}_{37}, \mathrm{~S}_{38}, \mathrm{~S}_{39}, \mathrm{~S}_{40}, \mathrm{~S}_{42} \text {, }\right. \\
\left.\mathrm{S}_{45}, \mathrm{~S}_{46}, \mathrm{~S}_{50}\right) \\
\text { Improving learning quality }\left(\mathrm{S}_{4}, \mathrm{~S}_{11}, \mathrm{~S}_{18}, \mathrm{~S}_{19}, \mathrm{~S}_{27}, \mathrm{~S}_{41}, \mathrm{~S}_{47}, \mathrm{~S}_{49}\right) \\
\text { Improving professional skills }\left(\mathrm{S}_{13}, \mathrm{~S}_{14}, \mathrm{~S}_{25}, \mathrm{~S}_{32}, \mathrm{~S}_{37}, \mathrm{~S}_{43}, \mathrm{~S}_{44}\right) \\
\left.\text { Active learning ( } \mathrm{S}_{3}, \mathrm{~S}_{9}, \mathrm{~S}_{20}, \mathrm{~S}_{41}, \mathrm{~S}_{48}\right) \\
\text { Communication with students }\left(\mathrm{S}_{2}, \mathrm{~S}_{50}\right) \\
\text { Self confidence }\left(\mathrm{S}_{13}, \mathrm{~S}_{43}\right) \\
\text { Transfer of information }\left(\mathrm{S}_{2}\right) \\
\text { Taking responsibility }\left(\mathrm{S}_{16}\right) \\
\text { Socialization }\left(\mathrm{S}_{17}\right)\end{array}$ \\
\hline
\end{tabular}

Int. J. Eval. and Res. Educ. Vol. 8, No. 2, June 2019: 299 - 312 
According to Table 13, except for one of the students, they think that authentic tasks are important for teacher training. When examining the important aspects, it is seen that student $\mathrm{S}_{2}$ is important in terms of gaining experience, how to convey the form and document to the student, and that student $\mathrm{S}_{3}$ is active in terms of learning and student $\mathrm{S}_{4}$ indicates that it is important in terms of learning quality. As for the students' opinions, the following statements are as follows:

Student $\mathrm{S}_{2}$ : It is important to train authentic teachers. So theoretically, we get the information. We are getting the information we need to transfer. However, we do not see exactly how to transfer the information, or we may have difficulties because we do not know what we are going to encounter when we transfer the information. I think these authentic tasks will be more important in terms of knowing how to meet and gain experience, and how to do it, and how to do it, not what to do and what to do.

Student $\mathrm{S}_{3}$ : ...I definitely think. Because practicing is very different from theory, taking theory and learning. You are becoming a different person. Therefore, when you read and memorize something, you work with a body that does not move physically with a brain that does not really work. However, in practice, it is necessary to be so competent that I am on the rise of the number of applications.

Student $\mathrm{S}_{4}$ : ...I definitely think. I think that the fact that the rate of learning by practicing is already ninety percent, the eighties are over the nineties, and this is the most important one, I think it should be an important place.

According to the results of the research, authentic evaluation significantly increases the academic achievement of teacher candidates. This result coincides with the studies in the literature. Bay et al. [24] concluded that authentic assessment with constructivist approach significantly increased the academic achievement of teacher candidates. Koçyiğit [29] also determined that the constructivist approach of authentic task oriented teachers significantly increased academic achievement and problem solving skills of teacher candidates. In the study conducted by Kinay [27], it was concluded that authentic evaluation practices conducted within the scope of scientific research methods significantly increased the problem solving skills of teacher candidates. In the study conducted by Karakoç [35] with secondary school students in foreign language education, it was determined that authentic task oriented applications increased the achievement of experimental group students more than the control group students did. Fook and Sidhu [36] also found in their research that formative assessment aspect of authentic assessment due to the active use of feedback was important in the achievements of graduate students. It can be said that authentic assessment involves a formative assessment that requires active use of feedback is a process-based evaluation. There are many studies in the literature that formative assessment is effective in students' academic achievement [37-40].

According to the results of the study, authentic assessment significantly increases the attitudes of teacher candidates towards measurement and evaluation in education. Koçyiğit [29] also found that authentic task-oriented practices significantly increased the attitudes of pre-school teacher candidates towards special teaching methods. In a study conducted with primary school students, Gündoğan [41] determined that the authentic task-based learning environment positively influenced the students' attitudes towards life lesson. In the research, also in authentic task-based learning environments, the students employed high-level thinking skills, developed different perspectives, shared real-life experiences, reflected, benefited from primary sources, worked collaboratively, moved communication out of class, assumed multiple roles, and associating with the experience of experts from real life. As a different result in a study using the same dependent variable, Kincal and Ozan [42] concluded that the formative assessment practices in which teacher candidates actively participated into the evaluation process positively affected their attitudes towards measurement and evaluation in education but not significantly increased them. This difference could be explained by the fact that, unlike authentic assessment, authentic tasks are not used in the formative assessment. In authentic assessment, it can be said that authentic tasks, especially authentic tasks, provide the students with a real life environment experience. Gulikers, Bastiaens and Kirschner [6] also stated that authentic tasks allowed students to acquire the skills they would need to use in solving future real-life problems.

The qualitative data obtained from unstructured diaries and semi-structured interview form show that prospective teachers' opinions about authentic assessment are quite positive. Prospective teachers think that authentic assessment combines theory and practice and is an important approach that helps them to gain characteristics such as professional experience and self-confidence. These results are parallel with the qualitative findings obtained in the literature regarding authentic assessment. Koçyiğit [29] found that prospective teachers had positive opinions about authentic assessment. The teacher candidates stated that they actively participated into the lesson and that evaluating themselves and their peers were more careful in the course, and that authentic tasks provided entertaining, motivating and lasting information. Kinay and Bahçeci [28] found that teacher candidates' opinions about authentic assessment were mostly positive. It was emphasized that the evaluation of the process together with the product, the evaluation of the process through 
real tasks and the fact that the evaluation was objective were positively reflected on the prospective teachers. In the research, it was determined that pre-service teachers defined their roles as the most active, researching, responsible and collaborative employees in authentic assessment. Fook and Sidhu [36] found that authentic assessment practices were more accepted by postgraduate students than traditional assessment practices. Dabbagh and Williams-Blijd [43] determined that although the students had confusion at the beginning and their anxiety levels were high, they were positive about their opinions about authentic teaching design. Gündoğan [41] found that primary school students and parents generally reported positive opinions about authentic task-based learning environments and found practices to be effective. Aydın-Așk [44] and Karakoç [35] found similar results in studies with secondary school students.

Another result of the research is related to the negative aspects of authentic assessment practices. The majority of pre-service teachers are of the opinion that there is no negative aspect of authentic assessment. Those who expressed their views about the negative aspect stated that the problems about the implementation of the authentic task were not the help of the school administrators; Dabbagh and WilliamsBlijd [43] found that students had difficulty in managing their own learning and in team process in terms of the difficulties experienced in authentic teaching process. In Koçyiğit's [29] study, prospective teachers reported problems in the evaluation process, which took a lot of time and was sometimes overly critical in their peer assessments.

Prospective teachers agree that authentic assessment is very important. In particular, they emphasize the importance of authentic assessment in terms of gaining professional experience, increasing professional skills, giving the opportunity to practice in real environment and increasing the quality of learning. Consistent with these results, the majority of teacher candidates stated that authentic assessment could be used in all courses and some courses could be used in appropriate courses. Kinay [27] also determined that most of the pre-service teachers want the course to be used in other courses as the way in which the course is taught is activated. Dilmaç and Dilmaç [25] also concluded that students want to use authentic assessment practices in other courses as well.

\section{CONCLUSION}

It was determined that authentic assessment significantly increased the academic achievement and attitude towards educational measurement of prospective teachers and also it's an approach that can serve to provide cooperation between the theory and practice which is a major problem in the field of teacher training in Turkey. Based on these results, as much as possible, authentic assessment practices can be included in teacher training. Seminars, panels and courses can be organized for the teaching staff to understand and apply the authentic assessment. Bureaucratic procedures can be facilitated in the permits to be taken from the Directorate of National Education for authentic task applications in schools. Future studies about it can be done for other levels of teaching. Studies on the effects of authentic assessment upon different dependent variables can be made.

\section{ACKNOWLEDGEMENTS}

This study held in Alanya on 24 April to 26 April 2017 was presented as oral presentations at the $1^{\text {st }}$ International Symposium of Limitless Education and Research (ISLER 2017).

\section{REFERENCES}

[1] Biggs J. and Tangs C, "Applying constructive alignment to outcomes-based teaching and learning. In training material for "quality teaching for learning in higher education" workshop for master trainers," Ministry of Higher Education, Kuala Lumpur, 2010.

[2] O'Farrell C, "Enhancing student learning through assessment," http://www.tcd.ie/teachinglearning/academicdevelopment/assets/pdf/250309_assessmen t_toolkit.pdf, 2005.

[3] Gelbal S and Kelecioğlu H, "Öğretmenlerin ölçme ve değerlendirme yöntemleri hakkındaki yeterlik algıları ve karşılaştıkları sorunlar", Hacettepe Üniversitesi Ĕğitim Fakültesi Dergisi, vol 33, pp. 135-145, 2007.

[4] Tynjälä P, "Towards expert knowledge? A comparison between a contructivist and a traditional learning environment in university," International Journal of Educational Research, vol 31(5), pp. 357- 442, 1999.

[5] Stiggins R and Chappuis J, "What a difference a word makes", Journal of Staff Development, vol 27(1), pp. 10-14, 2006.

[6] Gulikers J T M, Bastiaens T J and Kirschner, P. A. "A five-dimensional framework for authentic assessment," Educational Technology Research and Development, vol 52(3), pp. 67-86, 2004.

[7] Darling-Hammond, L. and Snyder, J. "Authentic assessment of teaching in context," Teaching and Teacher Education, vol 16, pp. 523-545, 2000.

Int. J. Eval. and Res. Educ. Vol. 8, No. 2, June 2019: 299 - 312 
[8] Koh K., "Authentic assessment, teacher judgment and moderation in a context of high accountability", In C. WyattSmith, V. Klenowski, and P. Colbert (Eds.), Designing assessment for quality learning, Dordrecht, The Netherlands: Springer, Vol. 1, pp. 249-264, 2014.

[9] Shepard L, Hammerness, K, Darling-Hammond, L, Rust, F, Snowden J B, Gordon E., ... Pacheco, A. "Assessment", In L. Darling-Hammond and J. Bransford (Eds.), San Francisco: John Wiley, Preparing teachers for a changing world, pp. 275-326, 2005.

[10] Koh K., "Authentic assessment," Oxford Research Encyclopedia of Education, 2016.

[11] Wiggins G., "A true test: Toward more authentic and equitable assessment", Phi Delta Kappan, vol 70(9), pp. 703-713, 1989.

[12] Wiggins G., "Educational assessment: Designing assessments to inform and improve student performance," San Francisco: John Wiley, 1998.

[13] Wiggins G., "Assessing student performance," San Francisco, CA: Jossey-Bass, 1993.

[14] Dochy F and McDowell L., "Assessment as a tool for learning," Studies in Educational Evaluation, vol 23(4), pp. 279-298, 1997.

[15] Raymond J, Homer C, Smith R and Gray J., "Learning through authentic assessment. An evaluation of a new development in the undergraduate midwifery curriculum," Nurse Education in Practice, vol 13(5), 471-476, 2013.

[16] Swaffield S., "Getting to the heart of authentic assessment for learning," Assessment in Education: Principles, Policy and Practice, vol 18(4), pp. 433-449, 2011.

[17] Gulikers J T M, Bastiaens T J, Kirschner P A and Kester L., "Relations between student perceptions of assessment authenticity, study approaches and learning outcome," Studies in Educational Evaluation, vol 32(4), pp. 381-400, 2006.

[18] Nicol D, Thomson A and Breslin, C., "Rethinking feedback practices in higher education: A peer review perspective," Assessment and Evaluation in Higher Education, vol 39(1), pp. 102-122, 2014.

[19] Pintrich P., "Multiple goals, multiple pathways: The role of goal orientation in self-regulated learning and achievement," Journal of Educational Review, vol 92, pp. 544-555, 2000.

[20] Vanaki Z and Memarian R., "Professional ethics: Beyond the clinical competency," Journal of Professional Nursing, vol 25, pp. 285-291, 2009.

[21] Wu X, Heng M and Wang W., "Nursing students' experiences with the use of authentic assessment rubric and case approach in the clinical laboratories," Nurse Education Today, vol 35, pp. 549-555, 2015.

[22] Villarroel V, Bloxham S, Bruna D, Bruna C and Herrera-Seda, C. "Authentic assessment: Creating a blueprint for course design," Assessment and Evaluation in Higher Education, vol 43(5), pp. 840-854, 2018.

[23] Aksu-Ataç B., "Foreign language teachers' attitude toward authentic assessment in language teaching", The Journal of Language and Linguistic Studies, vol 8(2), pp. 7-19, 2012.

[24] Bay E, Küçükoğlu A, Kaya H İ, Köse E, Ozan C, Taşgın A and Gündoğdu K., "Öğretmen eğitiminde otantik değerlendirmenin öğrenen başarısı ve tutumuna etkisi," I. Ulusal Ĕgitim Programları ve Öğretim Kongresi’nde sunulan bildiri, Turkey, 2010.

[25] Dilmaç S and Dilmaç O., "Otantik değerlendirme yaklaşımlarının ortaöğretim öğrencilerinin görsel sanatlar dersine yönelik tutumlarına etkisi," Buca Eğitim Fakültesi Dergisi, vol 38, pp. 1-35, 2014.

[26] Karakuş F., "Sosyal bilgiler öğretiminde yapıcı öğrenme ve otantik değerlendirme yaklaşımlarının öğrencilerin akademik başarı, kalıcılık ve sosyal bilgiler dersine yönelik tutumlarına etkisi," (Unpublished doctoral dissertation), Çukurova Üniversitesi, Adana, 2006.

[27] Kinay İ., "Otantik değerlendirme yaklaşımının öğretmen adaylarının problem çözme becerileri ile öğrenmeye ve katılımcı değerlendirmeye yönelik inançlarına etkisinin incelenmesi," (Unpublished doctoral dissertation), Gaziantep Üniversitesi, Gaziantep, 2015.

[28] Kinay İ. and Bağçeci B., "Sınıf öğretmeni adaylarının otantik değerlendirme sürecine yönelik görüşlerinin incelenmesi," Elektronik Eğitim Bilimleri Dergisi, vol 3(6), pp. 39-50, 2014.

[29] Koçyiğit S., "Otantik görev odaklı yapılandırmacı yaklaşımın öğretmen adaylarının başarılarına, derse karşı tutumlarına ve problem çözme becerilerine etkisi," (Unpublished doctoral dissertation), Marmara Üniversitesi, İstanbul, 2011.

[30] Campbell D T and Stanley J C., "Experimental and quasi-experimental designs for research," USA, Houghton Miffl in Company, 1963.

[31] Yin R K., "Case study research design and methods (3rd ed.)," London: Sage Publications, 2003.

[32] Bryant N C and Barnes L L B., "Development and validation of the attitude toward educational measurement inventory," Educational and Psychological Measurement, vol 57, pp. 870-875, 1997.

[33] Ozan C and Köse E., "Adaptation of Attitudes toward Educational Measurement Inventory (ATEMI) to Turkish," e-International Journal of Educational Research, vol 4(2), pp. 29-47, 2013.

[34] Miles M B and Huberman A M, "Qualitative data analysis (2nd ed.)," London: Sage Publication, 1994.

[35] Karakoç B, "Otantik görev odaklı uygulamaların yabancı dil eğitimine etkisinin incelenmesi," (Unpublished doctoral dissertation), Gaziantep Üniversitesi, Gaziantep, 2016.

[36] Fook C Y and Sidhu G K., "Authentic assessment and pedagogical strategies in higher education," Journal of Social Sciences, vol 6(2), pp. 153-161, 2010.

[37] Black P and Wiliam D., "Assessment and classroom learning”, Assessment in Education, vol 5(1), pp. 7-74, 1998.

[38] Kingston N and Nash B., "Formative assessment: A meta-analysis and a call for research," Educational Measurement: Issues and Practice, vol 30(4), pp. 28-37, 2011.

[39] Ozan C and Kincal R Y., "The effects of formative assessment on academic achievement, attitudes toward the lesson,and self-regulation skills," Educational Sciences: Theory and Practice, vol 18(1), pp. 85-118, 2018.

The effect of authentic assessment on academic achievement and attitude towards... (Ceyhun Ozan) 
[40] Ruiz-Primo M A and Furtak E M., "Exploring teachers' informal formative assessment practices and students' understanding in the context of scientific inquiry," Journal of Research in Science Teaching, vol 44(1), pp. 57-84, 2007.

[41] Gündoğan A., "Hayat bilgisi dersinde otantik görev temelli öğrenme ortamlarının öğrencilerin derse yönelik tutumlarına ve öğrenme süreçlerine yansıması," (Unpublished doctoral dissertation), Anadolu Üniversitesi, Eskişehir, 2017.

[42] Kincal R Y and Ozan C., "Effects of formative assessment on prospective teachers' achievement, attitudes and selfregulation skills," International Journal of Progressive Education, vol 14(2), pp. 77-92, 2018.

[43] Dabbagh N Dr and Williams-Blijd C., "Students' perceptions of their learning experiences in an authentic instructional design context," Interdisciplinary Journal of Problem-Based Learning, vol 4(1), pp. 6-29, 2010.

[44] Aydın-Aşk Z., "Matematik dersinde otantik görev odaklı öğrenme süreçlerinin incelenmesi: Bir eylem araştırması," (Unpublished doctoral dissertation), Gaziantep Üniversitesi, Gaziantep, 2016.

Int. J. Eval. and Res. Educ. Vol. 8, No. 2, June 2019: 299 - 312 